\title{
Death Receptor-Ligand Systems in Cancer, Cell Death, and Inflammation
}

\author{
Henning Walczak \\ Centre for Cell Death, Cancer, and Inflammation (CCCI), UCL Cancer Institute, University College \\ London, London WC1E 6BT, United Kingdom \\ Correspondence: h.walczak@ucl.ac.uk
}

\begin{abstract}
The discovery of tumor necrosis factor (TNF) marked the beginning of one of the most fascinating journeys in modern biomedical research. For the moment, this journey has culminated in the development of drugs that inhibit TNF. TNF blockers have revolutionized the treatment of many chronic inflammatory diseases. Yet, the journey seems far from over. TNF is the founding member of a family of cytokines with crucial functions in cell death, inflammation, and cancer. Some of these factors, most prominently TNF, CD95L, and TRAIL, can induce cell death. The receptors that mediate this signal are therefore referred to as death receptors, even though they also activate other signals. Here I will take you on a journey into the discovery and study of death receptor-ligand systems and how this inspired new concepts in cancer therapy and our current understanding of the interplay between cell death and inflammation.
\end{abstract}

$T_{\text {ingeng }}^{\text {ung }}$ umour necrosis facrtor (TNF) is the founding member of the TNF superfamily (TNFSF) of cytokines. The receptors for TNFSF ligands are known as the TNF receptor superfamily (TNFRSF). Some of them are capable of inducing cell death. They can do so because they contain a cytoplasmic death domain (DD). Presence of the DD defines a subgroup of the TNFRSF known as death receptors. Despite their name, death receptors can also induce other signals. They do so by activation of transcription factors and subsequent gene activation. Indeed, soon after its discovery it became clear that the most prominent function of TNF is the induction of cytokines and chemokines, and that TNF plays a crucial role in the inflammatory cascade.
There are six human death receptors (DRs): TNF-R1 (Loetscher et al. 1990; Schall et al. 1990), CD95 (Fas/APO-1) (Itoh et al. 1991; Oehm et al. 1992), TRAIL-R1 (DR4) (Pan et al. 1997b), TRAIL-R2 (APO-2/TRICK/DR5/KILLER) (Pan et al. 1997a; Screaton et al. 1997a; Sheridan et al. 1997; Walczak et al. 1997; Wu et al. 1997), DR3 (TRAMP/APO-3) (Chinnaiyan et al. 1996; Kitson et al. 1996; Bodmer et al. 1997; Screaton et al. 1997b), and DR6 (Pan et al. 1998). They are stimulated by their respective ligands. These are TNF, CD95L (FasL), TRAIL, and TL1A, respectively (Carswell et al. 1975; Suda et al. 1993; Wiley et al. 1995; Migone et al. 2002), with the ligand for DR6 not known, or at least the one suggested (Nikolaev et al. 2009) not yet confirmed (Fig. 1). Therefore,

Editors: Eric H. Baehrecke, Douglas R. Green, Sally Kornbluth, and Guy S. Salvesen

Additional Perspectives on Cell Survival and Cell Death available at www.cshperspectives.org

Copyright (C) 2013 Cold Spring Harbor Laboratory Press; all rights reserved; doi: 10.1101/cshperspect.a008698

Cite this article as Cold Spring Harb Perspect Biol 2013;5:a008698 
H. Walczak

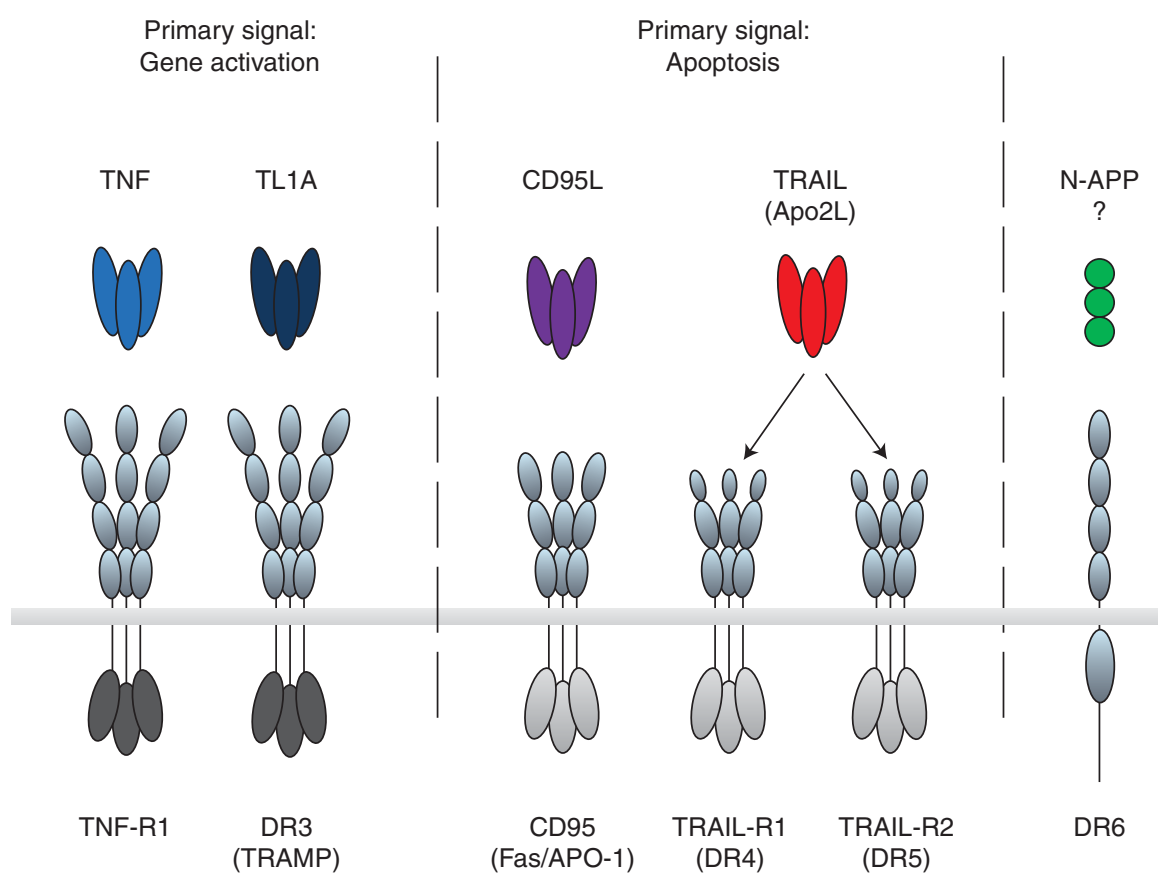

Figure 1. Death receptors and their ligands. The death domain-containing receptors are transmembrane proteins that contain 2-4 cysteine-rich repeats in their extracellular domain, required for ligand binding, and an intracellular death domain capable of recruiting specific adaptors that define their downstream interactors and signals (light gray for CD95/TRAIL and dark gray for TNF-R1/DR3 systems). Death receptors trigger two main signals. TNF-R1 and DR3 induce gene activation as their primary signaling output, whereas CD95, TRAIL-R1, and TRAIL-R2 induce apoptosis as their primary signal. DR6 has been proposed to be ligated by N-APP but this is unconfirmed, and DR6 signaling is altogether less well understood.

and because the biochemistry of the TL1A/DR3 system is highly similar to that of the TNF/TNFR1 system, this work focuses on the TNF, CD95, and TRAIL systems.

\section{A TUMOR-NECROTIZING ACTIVITY, TNF, AND AN UNEXPECTED TURN OF FORTUNE}

At the end of the nineteenth century, William Coley, at the time a young surgeon in New York, observed that in some cancer patients, especially sarcoma patients, who then contracted serious bacterial infections, the tumor necrotized and disappeared (reviewed in Hall 1997). Coley was so intrigued by this observation that over the next decades he developed and used a series of mixtures of bacterial isolates, which became known as "Coley's toxins" for the treatment of cancer. In some of his patients he could reproduce the tumor-necrotizing activity that led him to embark on this line of research (reviewed in Nauts et al. 1946, 1953). Obviously, back then, there were no means to identify the molecules and mechanisms behind this activity and the extracts could also not be produced with the same quality and activity each time. It took until 1944 when lipopolysaccharide (LPS) was isolated from bacterial extracts and identified as the active ingredient therein responsible for triggering tumor necrosis in mice (Shear and Perrault 1944). The availability of new molecular techniques in biochemistry and genetics in the 1960s and 1970s enabled a more rigorous investigation of the tumor-necrotizing activity of LPS and led to the identification of TNF by Lloyd Old and colleagues in 1975 (Carswell et al. 1975). 
In the decade following the discovery of TNF it emerged, however, that only few cancer cells died when stimulated by TNF. Instead, systemic treatment with TNF exerted a lethal inflammatory shock syndrome (reviewed in Tracey et al. 1988). Even though this observation was initially discouraging, it inspired the most important discovery of the TNF field to date: the inhibition of TNF to treat inflammatory diseases. Given that TNF can induce the above-mentioned shock syndrome, TNF blockers were first tried in the treatment of sepsis but these clinical trials failed. Around this time, Feldmann and colleagues in London showed that inhibition of TNF prevented collagen-induced arthritis, a model for rheumatoid arthritis (RA) (Williams et al. 1992). When TNF inhibition was tested clinically in RA, it turned out that a large percentage of patients benefited hugely from the treatment (reviewed in Taylor and Feldmann 2009). Today, millions of patients suffering from RA, Crohn's disease, and psoriasis, but also other chronic inflammatory diseases, are treated with TNF blockers with success rates often higher than 50\%. TNF blockers have revolutionized the therapy of chronic inflammatory diseases. Their development can be regarded as one of the most significant advances in recent biomedical research.

With respect to cancer treatment, however, TNF could not hold the early promise because of the before-mentioned systemic toxicity. Yet, in 1989, the concept of direct induction of cell death in cancer cells by an extracellular stimulus received a new lifeline: two monoclonal antibodies, anti-APO-1 and anti-Fas, were found to induce apoptosis in many different types of cancer cells by binding to a receptor on the surface of the cells they killed (Trauth et al. 1989; Yonehara et al. 1989).

\section{PHYSIOLOGICAL AND PATHOLOGICAL FUNCTIONS OF THE CD95 SYSTEM}

When the anti-APO-1 and anti-Fas antibodies and the antigens they bound to were first described, they appeared to recognize two different proteins. Anti-APO-1 was described to bind to a receptor of $\sim 48 \mathrm{kD}$ (Trauth et al. 1989), whereas anti-Fas was reported to detect a protein of $\sim 200 \mathrm{kD}$ (Yonehara et al. 1989). Yet the way the cells died when stimulated by these antibodies appeared very similar (Trauth et al. 1989; Yonehara et al. 1989), questioning whether the antibodies indeed engaged different receptors. Naturally, the next task was to identify the respective antigens. Nagata's team in Osaka performed expression cloning, whereas Krammer's team in Heidelberg took the classical approach of protein purification. Despite the above-described differences in the initial biochemical characterization, the same receptor of $\sim 48 \mathrm{kD}$, now commonly referred to as Fas (APO-1) or CD95, was engaged by both antibodies (Itoh et al. 1991; Oehm et al. 1992). CD95 contained a characteristic sequence in its extracellular domain, three cysteine-rich repeats that were also present in the two then recently cloned TNF receptors (Loetscher et al. 1990; Schall et al. 1990; Smith et al. 1990). Hence, the TNF and CD95 systems were related.

When Nagata's team mapped the gene encoding murine CD95 they realized that it localized to the same chromosomal region as the $l p r$ mutation, and indeed, a mutation in the CD95 gene was responsible for the accumulation of lymphocytes that characterizes lpr mice (Watanabe-Fukunaga et al. 1992). T-cell accumulation in these mice had been mistaken for lymphoproliferation (lpr), hence the name of the mutation, which illustrates the focus on proliferation rather than cell death in biomedical research at the time. A similar phenotype was observed in gld (generalized lymphoproliferative disease) mice (Roths et al. 1984). Elegant bone marrow transplantations from gld to $l p r$ mice and vice versa showed that the genes mutated in $l p r$ and gld mice encoded proteins expressed by cells that interact with each other in vivo (Reap et al. 1993). Thus, given the CD95 gene was mutated in $l p r$, the gld mutation most likely affected the gene encoding the elusive CD95 ligand (CD95L/FasL). When the Nagata team identified CD95L (Suda et al. 1993), they indeed found CD95L to be mutated in gld mice (Suda and Nagata 1994; Takahashi et al. 1994).

But what caused the aberrant phenotype in lpr and gld mice? This question was solved when 
H. Walczak

the Krammer team, as well as teams led by Green in San Diego, Marshak-Rothstein in Boston, and Lynch in Seattle discovered that CD95 and its ligand mediated activation-induced cell death (AICD) in T cells (Alderson et al. 1995; Brunner et al. 1995; Dhein et al. 1995; Ju et al. 1995). Thus, failure to undergo AICD results in accumulation of aberrant $\mathrm{T}$ cells in gld and $l p r$ mice. Teams led by Zinkernagel and Tschopp discovered that CD95L was also responsible for the long-sought-after perforin-independent cytotoxic activity of killer $\mathrm{T}$ cells (Lowin et al. 1994a,b; Berke 1995; Ehl et al. 1996). Hence, the CD95 system plays crucial roles in immune homeostasis and killer T-cell activity. The realization of the latter was promising because research on CD95 was of course initially fueled by the hope that CD95 agonists could be used in cancer therapy. However, when animals were treated systemically with antibodies to CD95 or recombinant CD95L that could interact with the receptors in the treated species, rather than only with receptors on the injected xenogeneic tumor cells, this induced massive hepatocyte apoptosis, resulting in fulminant hepatitis and acute death of the animals (Ogasawara et al. 1993).

Obviously, this was as disappointing a finding regarding the possibility of using CD95 agonists in cancer therapy as the previous realization that TNF could not be used for systemic cancer therapy. Yet, like with TNF, it turned out to mark the beginning of an entirely different but equally exciting field of research. If CD95 agonists could exert such drastic toxic effects in vivo, was it possible that CD95L-induced apoptosis could be involved in acute tissue damage that occurs in various pathological conditions? Since then, ample evidence has been gathered for the involvement of the CD95 system in various situations of acute tissue damage including graft-versus-host disease (Baker et al. 1996; Braun et al. 1996; Via et al. 1996a,b; Miwa et al. 1999) and some (Galle et al. 1995; Kondo et al. 1997; Strand et al. 1998, 2004), but not all, forms of acute liver damage (Oyaizu et al. 1997). CD95L has also been reported to be implicated in tissue damage following acute myocardial infarction (Jeremias et al. 2000; Lee et al.
2003), stroke (Vogt et al. 1998; Martin-Villalba et al. 1999), and spinal cord injury (Demjen et al. 2004; Ackery et al. 2006). These findings suggest that CD95L inhibitors may be useful therapeutics in situations in which normal tissue is acutely damaged.

An additional application of CD95L inhibitors emerged from a completely different line of research. Shortly after the discovery of the CD95 system, first reports appeared that CD95 stimulation does not always induce apoptosis but can also stimulate proliferation (e.g., in CD3-activated T cells) (Alderson et al. 1993, 1994, 1995; Desbarats et al. 1999; Kennedy et al. 1999), fibroblasts (Freiberg et al. 1997), and hepatocytes following partial hepatectomy (Desbarats and Newell 2000). Intriguingly, certain cancer cells also responded to CD95 stimulation by increasing their proliferation (OwenSchaub et al. 1993) or their motility and invasiveness (Barnhart et al. 2004). Recently, Peter and colleagues found that the protumorigenic role of CD95 seems to be a more general principle across many cancers (Chen et al. 2010). Intriguingly, on the basis of the biochemical tool we had generated to understand the role of the CD95-CD95L interaction in AICD of T cells (Dhein et al. 1995) and results obtained in a preclinical glioblastoma model (Kleber et al. 2008), a first biotherapeutic CD95L blocker was recently successfully tested in a phase II study in glioblastoma patients.

It will be fascinating to see how clinical testing of CD95L inhibition in cancer, but also the various other diseases outlined above, will unfold. It appears though that, as with TNF, the medical applications in the CD95 system are significantly more likely to derive from antagonizing the ligand, rather than stimulating the receptor.

\section{THE TRAIL APOPTOSIS SYSTEM AND ITS POTENTIAL FOR CANCER THERAPY}

Shortly after it became clear that also CD95L could not hold TNF's promise, a new TNF family member with an interesting activity profile was discovered. In 1995, Wiley and colleagues at Immunex in Seattle and Ashkenazi 
and colleagues at Genentech in San Francisco, independently found an expressed sequence tag (EST) in the public database with homology to CD95L, which was even annotated as such. The TNF-related apoptosis-inducing ligand (TRAIL), or Apo2L, as these groups named it, respectively, killed many cancer, but not normal, cells in vitro (Wiley et al. 1995; Pitti et al. 1996). So, was TRAIL going to finally fulfill TNF's promise?

In 1999, we at Immunex and Ashkenazi's team at Genentech found that systemic treatment of tumor-bearing mice with recombinant TRAIL killed tumor cells in vivo (Ashkenazi et al. 1999; Walczak et al. 1999). Importantly, a highly active form of TRAIL, capable of inducing apoptosis in mouse cells, neither induced a systemic shock syndrome, as seen with TNF, nor fulminant toxic effects owing to apoptosis induction, as observed with CD95L (Walczak et al. 1999). This meant that with TRAIL a TNF-like cytokine could be used systemically to kill tumor cells without being toxic.

Given TRAIL's potential to induce apoptosis in cancer but not normal cells, the receptor responsible for mediating this activity appeared to be an attractive target for the development of agonists capable of cross-linking it. The result of the race for the cloning of this receptor was quite surprising as TRAIL has five receptors of which two can mediate apoptosis.

At the time, in 1996 and 1997, many new human genes with homology to already known members of interesting protein families, like TRAIL itself, were found in EST databases. The EST "data mining" approach of a privately owned database led to the discovery of the first apoptosis-inducing receptor for TRAIL, now referred to as TRAIL-R1 or DR4, by the Dixit team (Pan et al. 1997a). Using a biochemical purification approach with TRAIL as bait we identified a different apoptosis-inducing receptor for TRAIL, TRAIL-R2 (Walczak et al. 1997). Shortly thereafter, TRAIL-R2 was also discovered by a number of other groups when its sequence appeared in public and private EST databases, and it received several other names including DR5, TRICK2, and KILLER (Pan et al. 1997a; Screaton et al. 1997a; Sheridan et al.
1997; Wu et al. 1997). In the following weeks and months, work by a number of groups led to the identification of two additional receptors for TRAIL, TRAIL-R3 (DcR1) and TRAIL-R4 (DcR2), which cannot induce apoptosis because they lack an intracellular DD (reviewed in Walczak and Krammer 2000). At first, these receptors were thought to exert a decoy function for TRAIL (hence the name "decoy receptor" $[\mathrm{DcR}])$ by being expressed on normal but not cancer cells. When the expression patterns of the TRAIL-Rs were analyzed, it became clear, however, that this concept did not hold. To this day we know little about the physiological function of these nondeath receptors for TRAIL. Finally, osteoprotegerin (OPG), a soluble, high-affinity receptor for RANKL, another member of the TNFSF, was found to interact with TRAIL, yet with lower affinity. It is rather unlikely that this interaction is relevant in vivo because mice overexpressing TRAIL do not show any bone-related phenotype, which would have been expected if TRAIL were capable of interacting with OPG in vivo, because in mice deficient for OPG, osteoclastogenesis is not inhibited and these mice therefore develop a strong bone-related phenotype (Simonet et al. 1997). In summary, TRAIL turned out to be the most promiscuous TNFSF member.

TRAIL-R1 and TRAIL-R2 share 58\% sequence homology and so far it has not been possible to identify significant distinct functions of one receptor versus the other. They both trigger apoptosis via the same pathway and, at present, even no differences to the CD95-engaged pathway are known. The big quest, therefore, is to identify the biochemical basis for the diametrically different outcome of the triggering of the TRAIL-Rs versus CD95 in normal cells, as the unraveling of this may lead the way to more targeted and patient-tailored applications of TRAIL in cancer treatment.

Based on the encouraging preclinical results with recombinant TRAIL in vivo (Ashkenazi et al. 1999; Walczak et al. 1999), Immunex and Genentech joined forces to explore the clinical potential of a first recombinant form of TRAIL in cancer treatment. Even though some clinical benefit has been detected in the various clinical 
trials in which this form of TRAIL has now been tested, the results of these trials were not nearly as striking as initially hoped. Apart from this form of TRAIL, "agonistic" antibodies to TRAIL-R1 and TRAIL-R2 have now been tested clinically (reviewed in Newsom-Davis et al. 2009).

Overall, the results of these studies are, however, disappointing. One reason for this is the absence of biomarkers to select patients who are likely to respond to TRAIL receptor agonist therapy, either alone or in combination with a particular TRAIL-sensitizing drug. To effectively use TRAIL-comprising cancer therapies, it will be crucial, however, to identify such biomarkers.

A perhaps more important reason for the lack of clear clinical activity of the currently developed TRAIL receptor agonists likely lies in their very nature, which simply renders them rather weak inducers of apoptosis. The recombinant form of TRAIL that has been developed clinically displays rather low apoptosis-inducing activity when compared with higher activity forms, perhaps also because the formulation of this ligand may not exactly match the biological moiety. Even though TRAIL had been suggested to be hepatotoxic (Lawrence et al. 2001), which may explain the hesitation to develop a more active form of TRAIL, we found that highly active forms of TRAIL are neither toxic to mice (Walczak et al. 1999) nor to primary human hepatocytes, even in combination with various TRAILsensitizing drugs (Ganten et al. 2005, 2006), suggesting that development and clinical application of high-activity forms of TRAIL and other TRAIL receptor agonists should be possible.

With respect to the antibodies, the failure likely has a different cause. Antibodies of the immunoglobulin $\mathrm{G}(\mathrm{IgG})$ type contain two antigen-binding sites. Triggering of TNFRSF members, however, requires cross-linking of at least three receptors for agonistic activity. Hence, IgG antibodies cannot do this without a cross-linking platform. This was first shown by the Krammer team for antibodies to CD95 (Dhein et al. 1992) and recently by the Genentech team for their clinically developed TRAIL-R2-specific antibody (Wilson et al. 2011).
As disappointing as it is that more than a decade after the demonstration of the tumorspecific apoptosis-inducing potential of a highly active form of TRAIL in vivo (Walczak et al. 1999) we still do not have a high-activity TRAIL receptor agonist in clinical use, it seems that this issue could soon be overcome with second-generation, high-activity TRAIL receptor agonists currently being bound for the clinic. It will be exciting to see how they fare, and whether TRAIL will finally be able to hold the promise that TNF and CD95L could not keep.

\section{CD95- AND TRAIL-INDUCED APOPTOSIS}

A prime goal for scientists working on CD95 was to elucidate how receptor cross-linking led to apoptosis induction in target cells. Nagata and colleagues made the first step by showing that apoptosis induction by CD95 required a part of the cytoplasmic domain, the DD (Itoh and Nagata 1993). They, as well as Goeddel and colleagues (Tartaglia et al. 1993), identified a similar DD in TNF-R1.

Discovery of FADD, Caspase-8, and the Death-Inducing Signaling Complex

Using yeast two-hybrid (Y2H), Dixit's team in Ann Arbor and Wallach's team in Rehovot discovered a protein they called FADD and MORT1, respectively, as a CD95-DD-interacting factor (Boldin et al. 1995a,b; Chinnaiyan et al. 1995). Apart from a DD that interacted with the CD95-DD, FADD also contained a second, DD-like domain, termed death-effector domain (DED). In the meantime, Kischkel and colleagues from the team led by Krammer and Peter biochemically studied the signaling complex that forms when CD95 is cross-linked to induce apoptosis. They dubbed this complex death-inducing signaling complex (DISC) and found that FADD and one additional, unidentified factor formed part of the CD95 DISC (Kischkel et al. 1995). Collaborating with Mann's team in Heidelberg, they determined the identity of the elusive second factor and, together with Dixit's team, were able to show how it works (Muzio et al. 1996). The identified 
factor was homologous to IL-1-converting enzyme (ICE) (Cerretti et al. 1992; Thornberry et al. 1992). CED-3, one of the key factors identified by Horvitz and colleagues in what later became a Nobel Prize-winning effort to define the genes required for cell death in Caenorhabditis elegans, was also homologous to ICE (Yuan and Horvitz 1990; Yuan et al. 1993). Consequently, the protein was named FLICE for FADD-like ICE. FLICE is FADD-like because it contains two DEDs that are homologous to the DED of FADD. The same protein was discovered by Wallach's team in a $\mathrm{Y} 2 \mathrm{H}$ screen with the DED of MORT1 (FADD). They named the protein MACH (Boldin et al. 1996). The protein formerly known as FLICE or $\mathrm{MACH}$ is now referred to as caspase-8. Caspases are cysteine-dependent aspartate-directed proteases (i.e., proteases that cleave target proteins at aspartic acid residues and use cysteine in their active center). There are 14 mammalian caspases (11 in humans and 10 in rodents) which, interestingly, have been classified as "apoptotic" or "inflammatory" (Creagh and Martin 2001; Salvesen and Riedl 2008; Pop and Salvesen 2009).

The mechanism of DISC formation and CD95-induced apoptosis identified is as follows: cross-linking of CD95 results in recruitment of FADD, which in turn recruits caspase- 8 to form the DISC. Caspase- 8 is then activated at the DISC, resulting in cleavage of downstream substrates. One of them is caspase-3, the mammalian homolog of CED-3 and crucial effector caspase in the apoptosis pathway (Creagh and Martin 2001). Once caspase-3 is activated it cleaves many vital cellular proteins responsible for the characteristic biochemical and morphological hallmarks of apoptosis. Thus, the discovery of caspase- 8 and its function at the DISC provided the missing link between CD95 cross-linking and the known part of the apoptosis pathway.

In the following years the process of DISC formation and downstream as well as regulatory events of CD95-induced apoptosis were further refined. Besides FADD and caspase-8, two related proteins, the cellular FLICE-like inhibitory protein (cFLIP) and caspase-10 (Irmler et al.
1997; Thome et al. 1997; Kischkel et al. 2001; Sprick et al. 2002), which both also contain DEDs, are recruited to the CD95 DISC. Although cFLIP lacks a catalytic cysteine in its active center and therefore blocks CD95-induced apoptosis, caspase-10 is highly homologous to caspase- 8 . To this day, however, the function of caspase-10 remains unclear (Kischkel et al. 2001; Sprick et al. 2002). Recently, the stoichiometry of the CD95 DISC was addressed. Surprisingly, these studies proposed that three receptors recruit one FADD protein and this FADD molecule recruits six to 10 DED-containing proteins (Fig. 2) (Dickens et al. 2012; Schleich et al. 2012).

Connecting the Death Receptor and the Mitochondrial Apoptosis Pathways

The proapoptotic $\mathrm{BH} 3$-only family member Bid was identified as a second critical substrate of caspase- 8 for engagement of the cellular apoptosis machinery (Gross et al. 1999; Yin et al. 1999). Caspase-8-cleaved, truncated Bid (tBid) translocates from the cytosol to mitochondria where it induces mitochondrial outer membrane permeabilization (MOMP), thereby activating the mitochondrial apoptosis pathway. These processes are discussed in detail in Green (2013). In the context of this work, however, there are two crucial points about these processes: (1) cleavage of Bid by caspase- 8 provides the missing link between the death receptor and mitochondrial apoptosis pathways, and (2) MOMP does not only induce release of cytochrome $c$ but also of the second mitochondrial activator of caspases (SMAC, also known as DIABLO). Whereas cytochrome $c$ release triggers apoptosome formation and activation of caspase-9, cytosolic SMAC binds to, and thereby neutralizes, the X-linked inhibitor of apoptosis protein (XIAP). XIAP, in turn, normally binds to, and thereby inhibits, caspase-8cleaved caspases 3 and 9. Hence, SMAC releases these caspases from their XIAP-imposed inhibition and cell death can finally ensue (Fig. 2).

Requirement for tBid-induced MOMP distinguishes so-called type I from type II cells. Type I cells do not require MOMP to undergo 
H. Walczak

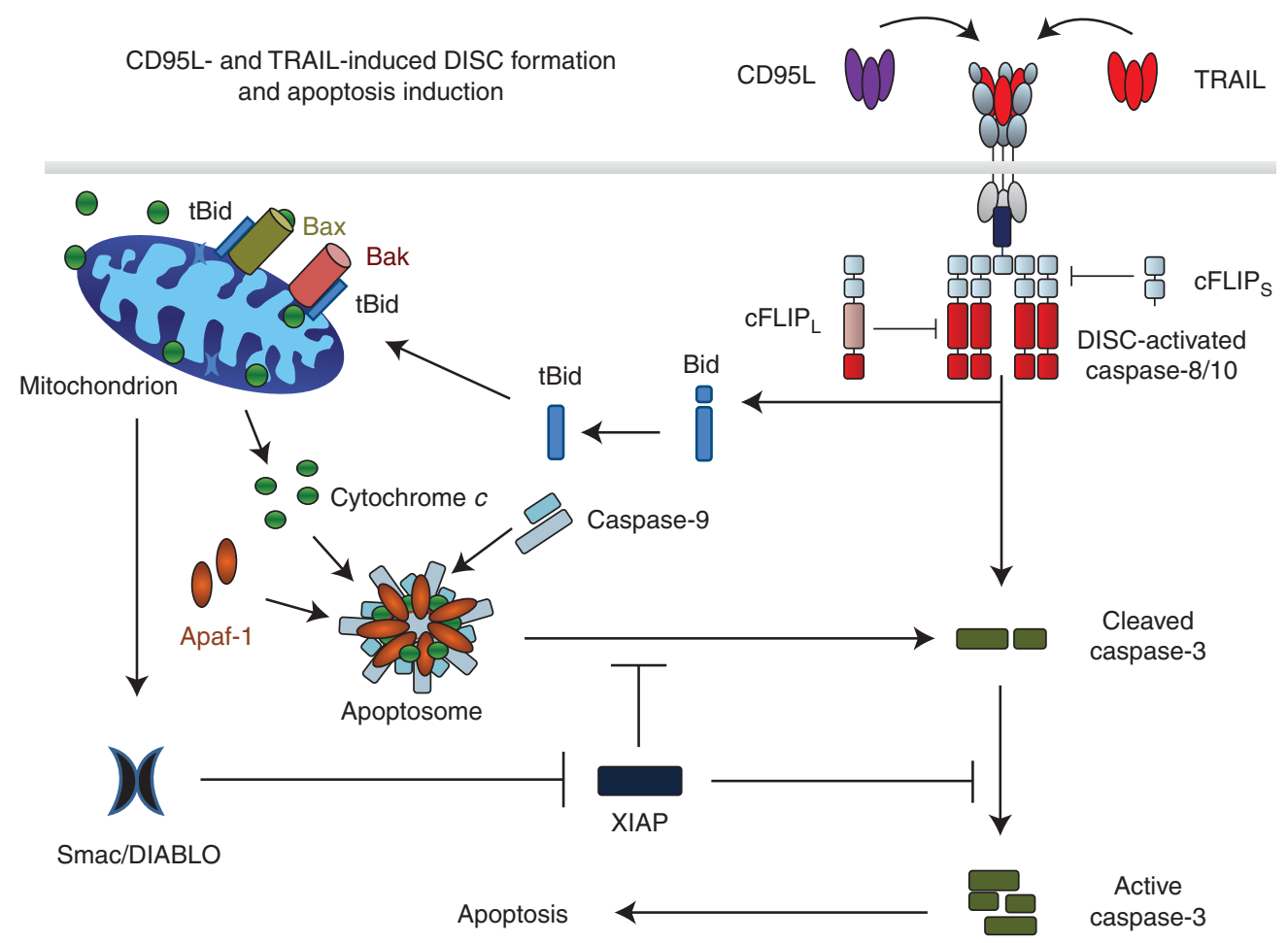

Figure 2. CD95L- and TRAIL-induced DISC formation and apoptosis induction. Binding of CD95L or TRAIL to their cognate receptors leads to receptor trimerization and formation of the death-inducing signaling complex (DISC). The DD of one FADD molecule interacts with the DDs of the three cross-linked receptors. Subsequently, procaspases 8 and 10 are recruited by interaction of their DED with that of FADD. Heterodimers between $\mathrm{CFLIP}_{\mathrm{L}}$ and caspase- 8 or -10 are not inactive as proteolytic enzymes but their proteolytic activity is edited as compared with caspase- 8 or -10 homodimers. CFLIP $_{S}$ in turn inhibits caspase activity at the DISC by preventing dimerization of caspase- $8 / 10 / \mathrm{cFLIP}_{\mathrm{L}}$. Interestingly, one FADD molecule recruits six to $10 \mathrm{DED}$ containing caspase- $8,-10$, and cFLIP proteins. DISC-activated caspase-8/-10 cleaves caspase-3, enabling autoactivation of caspase- 3 , which renders the enzyme fully active. This latter step can, however, be blocked by Xlinked inhibitor of apoptosis protein (XIAP). DISC-activated caspase-8/-10 also cleaves Bid (tBID). Interaction of tBid with Bak and Bax in the mitochondrial outer membrane induces Bax/Bak oligomerization, resulting in mitochondrial outer-membrane permeabilization (MOMP) so that cytochrome $c$ and Smac/DIABLO are released from the mitochondrial intermembrane space to the cytosol. Cytochrome $c$, together with Apaf-1 and caspase-9, forms the apoptosome, the activation platform for caspase-9, which can, however, also be inhibited by XIAP. Smac/DIABLO binds to XIAP, which releases caspase- 3 and -9 from XIAP-imposed inhibition. Activation of these caspases enables execution of apoptotic cell death.

CD95-induced apoptosis—even though it may nevertheless occur-whereas type II cells do (reviewed in Peter and Krammer 1998). In cells expressing a high XIAP/caspase-3 ratio, full activation of caspase- 3 following caspase-8-mediated cleavage is blocked. Therefore, XIAP is a crucial factor for categorizing cells as type I or type II regarding CD95-mediated apoptosis (Jost et al. 2009). Differences in CD95 DISC formation, first thought to be solely responsible for the type I/type II distinction (reviewed in Peter and Krammer 1998), likely contribute to this categorization through different caspase activity outputs of the DISC in type I versus type II cells. Hence, the balance between DISC-generated caspase activity and XIAP/caspase- 3 ratio is decisive for categorization of a given cell as type I or type II. 


\section{TRAIL-Induced Apoptosis}

Once the TRAIL receptors were cloned, the pathway of TRAIL-induced apoptosis was investigated. Despite the initial claim that TRAIL would not use FADD as adaptor (Marsters et al. 1996; Pan et al. 1997b), we and others showed that both TRAIL-R1 and TRAIL-R2 use FADD and caspase-8 (Walczak et al. 1997; Kischkel et al. 2000, 2001; Sprick et al. 2000, 2002), just like CD95 (Fig. 2). It has been a conundrum that agonists of CD95 are so toxic, whereas even highly active TRAIL receptor agonists are not (Walczak et al. 1999), even when combined with TRAIL-apoptosis-sensitizing drugs (Ganten et al. 2005, 2006; Koschny et al. 2007). Solving this conundrum will be an important step forward in understanding the biology of death receptors in general but particularly for the use of TRAIL receptor agonists in cancer therapy.

\section{TNF-/TNF-R1-INDUCED GENE ACTIVATION AND CELL DEATH}

TNF has two cellular receptors. Whereas TNF$\mathrm{R} 1$ is expressed in many tissues, TNF-R2 is almost exclusively present on lymphoid and endothelial cells. TNF-R1 contains a DD, whereas TNF-R2 does not. TNF-R1 initiates the majority of TNF-induced biological activities, including induction of cell death (Wajant et al. 2003).

\section{The TNF-R1 Signaling Complex (TNF-RSC)}

Binding of TNF to TNF-R1 triggers a series of intracellular events, but the primary output is activation of NF- $\kappa \mathrm{B}$ and the mitogen-activated protein kinases (MAPKs) c-Jun amino-terminal kinase (JNK) and p38. The resulting gene activation is crucial for the inflammatory response to infection. Induction of cell death by TNF is a secondary signal that is only triggered when the gene-activatory signals are too weak or otherwise perturbed.

Binding of TNF to TNF-R1 induces receptor oligomerization and formation of the TNFR1 signaling complex (TNF-RSC), which is initiated by recruitment of the DD-containing proteins TRADD and RIP1 to the DD of the receptor (Fig. 3). TRADD then recruits TRAF2, which in turn serves as a recruitment platform for cIAP1 and cIAP2. cIAPs are E3 ubiquitin ligases and, following their recruitment to the TNF-RSC, they polyubiquitinate RIP1, which enables activation of NF- $\kappa \mathrm{B}$ and MAPKs. Ubiquitin chains can be formed via linkages of the ubiquitin subunits on different $\varepsilon$-amino groups of the seven lysines present in ubiquitin or via the $\alpha$-amino group at the amino terminus of ubiquitin, the latter creating linear ubiquitin chains (Rieser et al. 2012). Until recently, it was thought that polyubiquitin chains involved in TNF signaling are either linked via the $\varepsilon$ amino groups of lysine 63 (K63) or K48 of ubiquitin. Recently, however, we showed that linear ubiquitin chains are also present on components of the TNF-RSC and are crucial in providing the physiological TNF signaling output (Gerlach et al. 2011). A protein complex termed LUBAC, for linear ubiquitin chain assembly complex, is recruited to the TNF-RSC in a cIAP-activity-dependent manner and required for activation of NF- $\mathrm{B}$ and MAPKs to the full physiologically required extent. This is most likely owing to the fact that NEMO binds more strongly to linear than K63-linked ubiquitin chains (Lo et al. 2009; Rahighi et al. 2009). Besides linear and K63 ubiquitin linkages, we also found K11 and K48 linkages on RIP1 in the native TNF-RSC (Gerlach et al. 2011). Hence, different forms of ubiquitin linkages cooperate to achieve the physiological signaling output of the TNF-RSC. This suggested the following model: Rather than one long K63-linked chain on RIP1, differently linked-possibly rather short-chains, which are placed in exact positions on various TNF-RSC components, enable precise construction of this protein complex, regarding both positioning of recruited functional units and timing of complex construction and deconstruction (Walczak 2011). Thereby, the functional units of the NEMO/ IKK and TAB/TAK complexes are recruited at exact times and into predefined positions within the complex so that the TNF-RSC works as designed and gene expression by NF- $\mathrm{KB}$ and 
H. Walczak

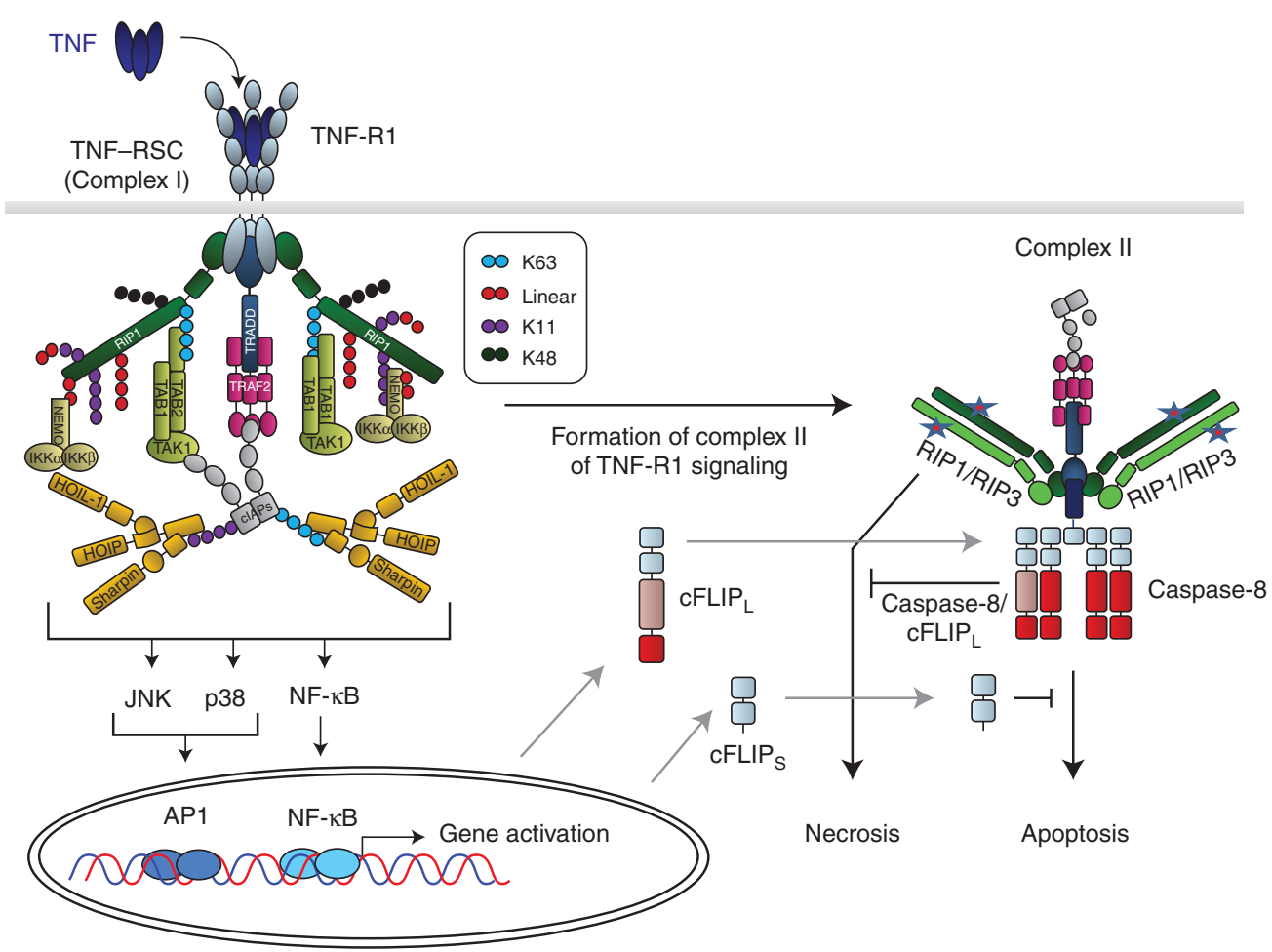

Figure 3. TNF-R1-induced gene activation and cell death signaling. Cross-linking of TNF-R1 by TNF results in formation of the TNF-R1 signaling complex (TNF-RSC). Cross-linked TNF-R1 recruits TRADD and RIP1 to the DD of the receptor. Subsequently, TRADD recruits TRAF2, which in turn provides the platform for cIAP1/2. cIAPs then place ubiquitin chains, linked via different interubiquitin linkages, on various TNF-RSC components. cIAP-Mediated ubiquitination is required to recruit LUBAC. Once recruited, LUBAC places linearly linked ubiquitin linkages on RIP1 and NEMO. Together, the different cIAP- and LUBAC-generated ubiquitin chains, placed in defined positions and sequences on specific components of the TNF-RSC, enable the physiologically required gene-activatory capacity of this complex by mediating the exact positioning of both the IKK and TAB/TAK complexes in the TNF-RSC. The different ubiquitin linkages are indicated in different colors. The depicted chain lengths, the sequence of the different linkages in them, and their exact positioning on different TNF-RSC components are only shown as examples in this model of the TNF-RSC as they are currently mostly unknown. Most likely involving the action of deubiquitinases (DUBs; not depicted here), the TNF-RSC releases TRADD, together with RIP1 and other cytoplasmic constituents of the complex, into the cytosol. This secondary complex, complex II, recruits FADD, caspase-8/10, and, when expressed, the different isoforms of cFLIP and RIP3. RIP1/3-induced necrosis from complex II is counteracted by the activity of the caspase-8/cFLIP $\mathrm{L}_{\mathrm{L}}$ heteromer, and FADD/caspase-8-mediated apoptosis by $\mathrm{CFLIP}_{\mathrm{S}}$ and possibly also by $\mathrm{cFLIP} \mathrm{L}_{\mathrm{L}}$. Depending on the relative presence of the components in complex II, it can therefore either initiate FADD/ caspase-8-dependent apoptosis or RIP1/RIP3-kinase-activity-dependent necrosis, or, when cFLIP and perhaps other, currently unknown inhibitory factors are present in the complex at sufficiently high levels, its cell-deathinducing capacity may be entirely inhibited.

AP-1 is activated exactly as intended and physiologically required (Fig. 3 ).

Disassembly of the complex is mainly mediated by so-called deubiquitinases (DUBs), enzymes that cleave ubiquitin from target proteins. It appears that certain DUBs, including the TNF-RSC-recruited A20, Cezanne, and CYLD, act in a ubiquitin-linkage-specific manner (i.e., they cleave certain types of interubiquitin linkages but not others) (Komander et al. 2009b). Their recruitment occurs later than that of the E3s and the functional units 
responsible for activating gene induction in response to TNF. At least with respect to A20, TNF-induced gene activation is decisive for the appearance of this protein in the complex (Gerlach et al. 2011). We are, however, only beginning to understand which DUBs cleave which interubiquitin linkages (Komander et al. 2009a), let alone in the context of particular RSCs or on specific components thereof. Likely, exact positioning of DUBs within RSCs and the timing thereof will be crucial.

\section{Complex II of TNF-R1 Signaling: Cell Death in Two Flavors}

When the TNF-RSC is deconstructed it does not disintegrate into its individual constituents. Micheau and Tschopp discovered that, following formation of the TNF-RSC, a second complex appears intracellularly that contains TRADD and some, but not all, of the other cytoplasmic components of the TNF-RSC. Additionally the cytoplasmic DISC components FADD, caspase-8, caspase-10, and cFLIP are also recruited to complex II of TNF-R1 signaling (Micheau and Tschopp 2003). It is, hence, an "intracellular DISC" whose formation temporally follows TNF-RSC (complex I) formation, and which generates the cell-death-inducing signals of TNF. However, when complex I works properly, complex II does not get to induce cell death because its signaling output is counteracted by the gene-activatory signals generated at complex I as these increase expression of prosurvival proteins, including the two isoforms of cFLIP, $\mathrm{cFLIP}_{\mathrm{L}}$, and $\mathrm{cFLIP}_{\mathrm{S}}$. Thus, if complex I is not decomposed prematurely and its output reaches physiological levels, complex II-induced cell death is prevented (Fig. 3).

It has long been known that TNF cannot only induce apoptotic but also necrotic cell death (reviewed in Vandenabeele et al. 2010). It emerged only recently, however, that TNFinduced necrosis is the result of a regulatable process that requires the kinase activities of both RIP1 and RIP3 (Holler et al. 2000; Hitomi et al. 2008; Cho et al. 2009; He et al. 2009; Zhang et al. 2009). For a long time it was a mystery why deficiency in caspase- 8 or FADD is embryoni- cally lethal if all they did was induce apoptosis. Recently, however, a plausible explanation was offered: Concomitant deletion of RIP3 or RIP1 rescued mice deficient for caspase- 8 or FADD from embryonic lethality (Kaiser et al. 2011; Oberst et al. 2011; Zhang et al. 2011). This means, on the one hand, that RIP1 and RIP3 mediate lethality induced by deficiency in caspase- 8 or FADD, but on the other, that the presence of caspase- 8 and FADD prevents this. Thus, besides their role in apoptosis induction, FADD and caspase- 8 also act together to prevent RIP1/RIP3-induced lethality. Interestingly, cFLIP deficiency is also lethal (Yeh et al. 2000). This lethality could only be reversed by concomitant deficiency in RIP3 and FADD but not when either factor was absent individually (Dillon et al. 2012). Thus, cFLIP is required for caspase- 8 and FADD to block RIP1/ RIP3-induced lethality (van Raam and Salvesen 2012), but also to interfere with caspase-8induced lethality. It appears that the different isoforms of cFLIP may play distinct roles in these processes as $\mathrm{CFLIP}_{\mathrm{S}}$ interferes with apoptosis and $\mathrm{cFLIP}_{\mathrm{L}}$ with necrosis and, at least at high expression levels, also with apoptosis (Kavuri et al. 2011). Hence, RIP1/RIP3- and caspase-8/FADD/cFLIP-mediated signals control each other at complex II. Interestingly, recent studies have shown that inflammation in mice deficient for caspase- 8 or FADD in either skin or gut (Kovalenko et al. 2009), does not occur when RIP3 is absent (Welz et al. 2011; Gunther et al. 2012). Whether this is solely because of prevention of RIP3-induced necrosis, or whether other RIP3-mediated signals may also play a role in preventing inflammation induced by deficiency in DISC components (Vince et al. 2012; Wallach et al. 2012), remains to be resolved.

In summary, our current model of the celldeath-inducing activities at complex II is as follows: FADD and caspase- 8 induce apoptosis, which is prevented in the presence of sufficient amounts of cFLIP that are also required, together with FADD as adaptor and caspase- 8 as an enzymatic partner, to interfere with RIP1/3-induced necrosis. There must be a fine balance between the two types of cell death induced by this complex, and the expression levels of cFLIP 
H. Walczak

isoforms likely play an important part in tipping it one way or the other (Fig. 3).

\section{INTEGRATING CELL DEATH AND INFLAMMATION}

TRAIL and CD95L cannot only induce apoptosis but also proinflammatory, proliferative, and promigratory signals (Ehrhardt et al. 2003; Budd et al. 2006; Peter et al. 2007; Wilson et al. 2009; Lemke et al. 2010; Roder et al. 2011). Some of these signals occur in a FADD/caspase-8-independent manner but the mechanisms are still debated (Green 2010). One suggestion has been that the Src-family kinase Yes and the p85 subunit of PI3 kinase associate with the membrane-proximal portion of CD95's cytoplasmic domain on cross-linking in glioblastoma cells and that the resulting activation of the $\mathrm{PKB} / \mathrm{AKT}$ pathway could be responsible for the protumorigenic signals induced by CD95L in glioblastoma (Sancho-Martinez and MartinVillalba 2009; Parrish et al. 2013).

More is known about the DD-requiring, nonapoptotic signals induced by CD95L or TRAIL. Interestingly, Ashkenazi and colleagues found that release of FADD from the TRAIL DISC triggers formation of an intracellular complex II by recruiting TRAF2, cIAP $1 / 2$, RIP1, NEMO, and most likely several other factors required for activation of NF- $\kappa$, MAPKs, and consequently, gene induction (Varfolomeev et al. 2005). Also in this case induction of signals from complex II does not occur, or at least only to a limited extent, when the primary signal induced by complex I, in this case the TRAIL DISC, results in cell death. This suggests the following model: Although the output of the primary complex of TNF-R1 signaling is gene activation, its second complex can induce two rather different forms of cell death. In the case of CD95 and TRAIL, the signaling output of the DISC is apoptosis, whereas that of complex II is gene activation (Fig. 4).

Why are specific tasks separated into different, sequentially acting signaling complexes? One explanation could be that, when the first signal prevails, the second one is not required or should at least be minimized. If, however, the primary signal does not reach its intended end point, signaling by the second complex is initiated. If a physiological extracellular stimulus (i.e., TRAIL or CD95L) triggers the apoptosis machinery in a cell but it does not die, this should alarm the organism because infectious agents often inhibit apoptosis. Hence, an alarm signal capable of stimulating immunity should be induced now. By activating proinflammatory gene induction, and perhaps necrosis, complex II of the CD95 and TRAIL systems can do exactly that (Fig. 4).

In the case of TNF-R1, and most likely DR3, it is the other way around. When proper gene activation cannot be achieved by complex I, complex II induces cell death. TNF-induced cell death can either be apoptotic or necrotic. It is unclear which type of TNF-induced cell death prevails when its gene-activatory pathway is perturbed, and it is likely that this differs with the type of perturbation. It is, however, likely that there will be an inflammatory component in it. Thereby, a biological outcome similar to the originally intended one could be achieved (i.e., the creation of a proinflammatory environment), yet by going down a very different path than originally intended (Fig. 4).

Interestingly, inflammation occurs in both autoimmunity and cancer. TNF has been shown to be intimately involved in both processes (Balkwill 2009; Taylor and Feldmann 2009). Yet, whereas autoimmunity-associated inflammation is immunostimulatory, cancer-related inflammation suppresses immunity. It is tempting to speculate that the two cell death modalities induced by TNF and its relatives, together with their gene-activatory capacity, are decisive in determining whether inflammation will stimulate or suppress immunity. Whatever the outcome will be, it is now clear that cell death and inflammation are more closely linked than previously thought and in fact seem to represent two sides of the very same coin.

\section{CONCLUDING REMARKS AND OUTLOOK}

Studying the TNF, CD95, and TRAIL death receptor ligands has provided tremendous insight into the biochemistry and function of cell death 


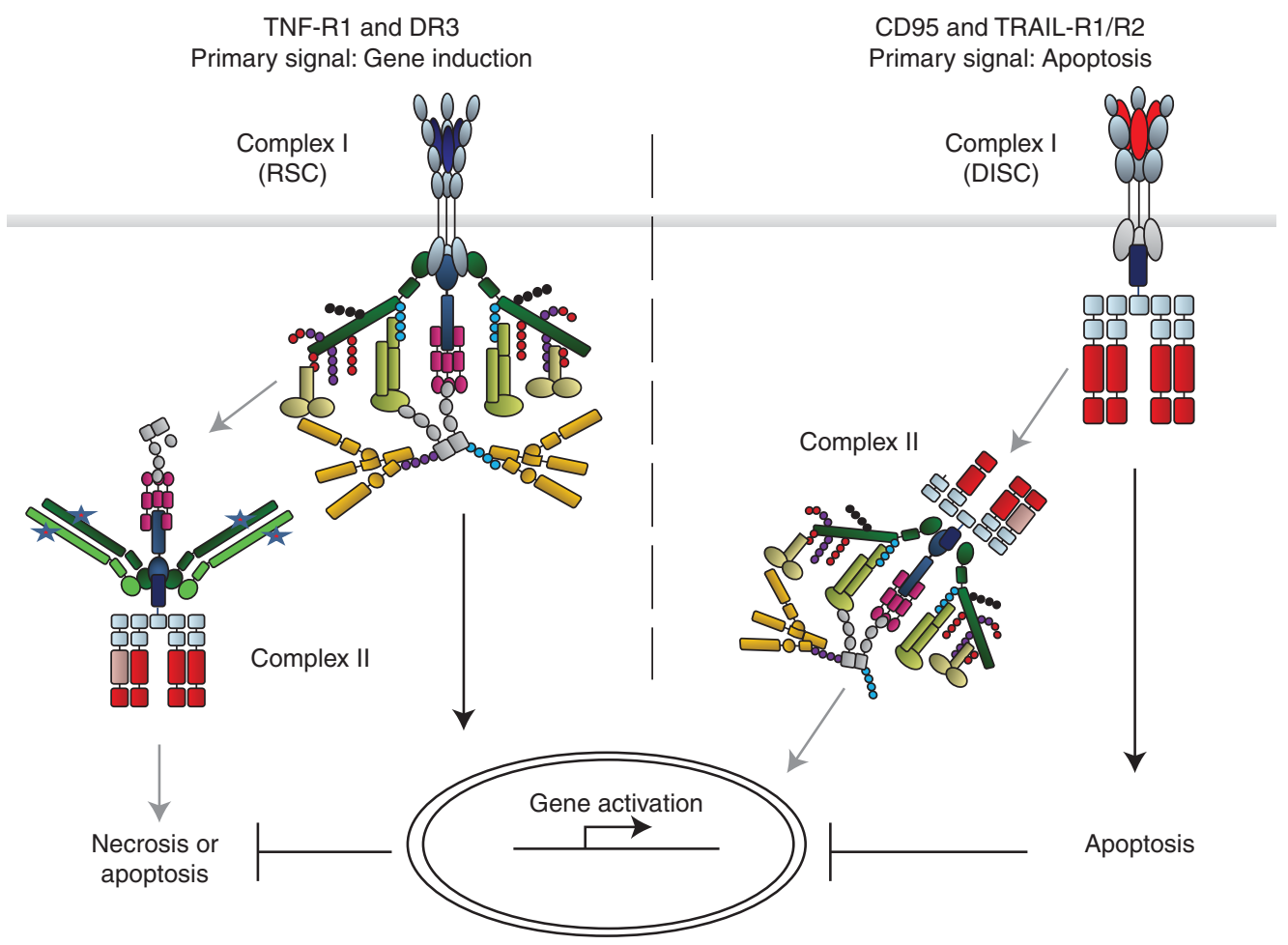

Figure 4. Comparison of CD95/TRAIL-R1/R2 and TNF-R1/DR3 signaling. For both the proapoptotic CD95 and TRAIL systems as well as the proinflammatory TNF and DR3 systems, the complex defined as complex I is the protein complex that forms at the plasma membrane and exerts the primary function of the respective receptor (i.e., apoptosis for CD95 and TRAIL-R1/R2 and gene activation via NF- $\mathrm{BB}$ and MAPK by TNF-R1 and $\mathrm{DR} 3)$. The two primary complexes dissociate from the $\mathrm{DD}$ of the respective receptor and recruit additional proteins from the cytosol to form complex II, which triggers the respective secondary signal. In the case of CD95 and TRAIL-R1/R2 the second signal is gene activation via the NF- $\mathrm{KB}$ and MAPK pathways; in the case of TNF$\mathrm{R} 1 / \mathrm{DR} 3$ it is induction of necrosis or apoptosis. The signaling outputs of the respective secondary complexes are prevented or attenuated in case the respective primary complexes reach theirs.

and inflammation. Importantly, however, this research has also yielded three classes of drugs: TNF blockers, CD95L inhibitors, and TRAIL receptor agonists. TNF blockers have transformed the treatment of chronic inflammatory diseases. CD95L inhibitors and TRAIL receptor agonists have now entered the clinic and it will be exciting to see how their clinical potential unfolds in the future.

The understanding of death receptor-mediated signaling pathways has been at the forefront of many fascinating developments in cell biology, most importantly in the fields of cancer, inflammation, and cell death. Among the promising future areas in death receptor sig- naling are the specific sensitization of cancer cells to TRAIL, the elucidation of the pathways of regulated necrosis and CD95-mediated protumorigenic signaling, the deciphering of the ubiquitin code in death receptor signaling, and the reciprocal regulation of apoptosis and necrosis. It is likely that studies into these processes will, at times, provide surprising results. That, however, comes as no surprise because the journey from Coley's discovery of a tumor-necrotizing activity to today's research on the biology of death receptor-ligand systems has been packed with surprises, making this journey an exciting one that promises to continue for some time to come. 
H. Walczak

\section{REFERENCES}

* Reference is also in this collection.

Ackery A, Robins S, Fehlings MG. 2006. Inhibition of Fasmediated apoptosis through administration of soluble Fas receptor improves functional outcome and reduces posttraumatic axonal degeneration after acute spinal cord injury. J Neurotrauma 23: 604-616.

Alderson MR, Armitage RJ, Maraskovsky E, Tough TW, Roux E, Schooley K, Ramsdell F, Lynch DH. 1993. Fas transduces activation signals in normal human $\mathrm{T}$ lymphocytes. J Exp Med 178: 2231-2235.

Alderson MR, Tough TW, Braddy S, Davis-Smith T, Roux E, Schooley K, Miller RE, Lynch DH. 1994. Regulation of apoptosis and $\mathrm{T}$ cell activation by Fas-specific mAb. Int Immunol 6: 1799-1806.

Alderson MR, Tough TW, Davis-Smith T, Braddy S, Falk B, Schooley KA, Goodwin RG, Smith CA, Ramsdell F, Lynch DH. 1995. Fas ligand mediates activation-induced cell death in human T lymphocytes. J Exp Med 181: $71-77$.

Ashkenazi A, Pai RC, Fong S, Leung S, Lawrence DA, Marsters SA, Blackie C, Chang L, McMurtrey AE, Hebert A, et al. 1999. Safety and antitumor activity of recombinant soluble Apo2 ligand. J Clin Invest 104: 155-162.

Baker MB, Altman NH, Podack ER, Levy RB. 1996. The role of cell-mediated cytotoxicity in acute GVHD after MHCmatched allogeneic bone marrow transplantation in mice. J Exp Med 183: 2645-2656.

Balkwill F. 2009. Tumour necrosis factor and cancer. Nat Rev Cancer 9: 361-371.

Barnhart BC, Legembre P, Pietras E, Bubici C, Franzoso G, Peter ME. 2004. CD95 ligand induces motility and invasiveness of apoptosis-resistant tumor cells. EMBO J 23: 3175-3185.

Berke G. 1995. The CTL's kiss of death. Cell 81: 9-12.

Bodmer JL, Burns K, Schneider P, Hofmann K, Steiner V, Thome M, Bornand T, Hahne M, Schroter M, Becker K, et al. 1997. TRAMP, a novel apoptosis-mediating receptor with sequence homology to tumor necrosis factor receptor 1 and Fas(Apo-1/CD95). Immunity 6: 79-88.

Boldin MP, Mett IL, Varfolomeev EE, Chumakov I, ShemerAvni Y, Camonis JH, Wallach D. 1995a. Self-association of the "death domains" of the p55 tumor necrosis factor (TNF) receptor and Fas/APO1 prompts signaling for TNF and Fas/APO1 effects. J Biol Chem 270: 387-391.

Boldin MP, Varfolomeev EE, Pancer Z, Mett IL, Camonis JH, Wallach D. 1995b. A novel protein that interacts with the death domain of Fas/APO1 contains a sequence motif related to the death domain. J Biol Chem 270: 77957798.

Boldin MP, Goncharov TM, Goltsev YV, Wallach D. 1996. Involvement of MACH, a novel MORT1/FADD-interacting protease, in Fas/APO-1- and TNF receptor-induced cell death. Cell 85: 803-815.

Braun MY, Lowin B, French L, Acha-Orbea H, Tschopp J. 1996. Cytotoxic T cells deficient in both functional fas ligand and perforin show residual cytolytic activity yet lose their capacity to induce lethal acute graft-versus-host disease. J Exp Med 183: 657-661.
Brunner T, Mogil RJ, LaFace D, Yoo NJ, Mahboubi A Echeverri F, Martin SJ, Force WR, Lynch DH, Ware CF, et al. 1995. Cell-autonomous Fas (CD95)/Fas-ligand interaction mediates activation-induced apoptosis in T-cell hybridomas. Nature 373: 441-444.

Budd RC, Yeh WC, Tschopp J. 2006. cFLIP regulation of lymphocyte activation and development. Nat Rev Immunol 6: 196-204.

Carswell EA, Old LJ, Kassel RL, Green S, Fiore N, Williamson B. 1975. An endotoxin-induced serum factor that causes necrosis of tumors. Proc Natl Acad Sci 72: 36663670 .

Cerretti DP, Kozlosky CJ, Mosley B, Nelson N, Van Ness K, Greenstreet TA, March CJ, Kronheim SR, Druck T, Cannizzaro LA, et al. 1992. Molecular cloning of the interleukin-1 $\beta$ converting enzyme. Science 256: 97-100.

Chen L, Park SM, Tumanov AV, Hau A, Sawada K, Feig C, Turner JR, Fu YX, Romero IL, Lengyel E, et al. 2010. CD95 promotes tumour growth. Nature 465: 492-496.

Chinnaiyan AM, O’Rourke K, Tewari M, Dixit VM. 1995. FADD, a novel death domain-containing protein, interacts with the death domain of Fas and initiates apoptosis. Cell 81: 505-512.

Chinnaiyan AM, O’Rourke K, Yu GL, Lyons RH, Garg M, Duan DR, Xing L, Gentz R, Ni J, Dixit VM. 1996. Signal transduction by DR3, a death domain-containing receptor related to TNFR-1 and CD95. Science 274: 990-992.

Cho YS, Challa S, Moquin D, Genga R, Ray TD, Guildford M, Chan FK. 2009. Phosphorylation-driven assembly of the RIP1-RIP3 complex regulates programmed necrosis and virus-induced inflammation. Cell 137: 1112-1123.

Creagh EM, Martin SJ. 2001. Caspases: Cellular demolition experts. Biochem Soc Trans 29: 696-702.

Demjen D, Klussmann S, Kleber S, Zuliani C, Stieltjes B, Metzger C, Hirt UA, Walczak H, Falk W, Essig M, et al. 2004. Neutralization of CD95 ligand promotes regeneration and functional recovery after spinal cord injury. Nat Med 10: 389-395.

Desbarats J, Newell MK. 2000. Fas engagement accelerates liver regeneration after partial hepatectomy. Nat Med 6: 920-923.

Desbarats J, Wade T, Wade WF, Newell MK. 1999. Dichotomy between naive and memory $\mathrm{CD} 4{ }^{+} \mathrm{T}$ cell responses to Fas engagement. Proc Natl Acad Sci 96: 8104-8109.

Dhein J, Daniel PT, Trauth BC, Oehm A, Moller P, Krammer PH. 1992. Induction of apoptosis by monoclonal antibody anti-APO-1 class switch variants is dependent on cross-linking of APO-1 cell surface antigens. J Immunol 149: 3166-3173.

Dhein J, Walczak H, Baumler C, Debatin KM, Krammer PH 1995. Autocrine T-cell suicide mediated by APO-1/(Fas $/$ CD95). Nature 373: 438-441.

Dickens LS, Boyd RS, Jukes-Jones R, Hughes MA, Robinson GL, Fairall L, Schwabe JW, Cain K, Macfarlane M. 2012. A death effector domain chain DISC model reveals a crucial role for Caspase- 8 chain assembly in mediating apoptotic cell death. Mol Cell 47: 291-305.

Dillon CP, Oberst A, Weinlich R, Janke LJ, Kang TB, BenMoshe T, Mak TW, Wallach D, Green DR. 2012. Survival 
function of the FADD-CASPASE-8-cFLIP(L) complex. Cell Rep 1: 401-407.

Ehl S, Hoffmann-Rohrer U, Nagata S, Hengartner H, Zinkernagel R. 1996. Different susceptibility of cytotoxic $\mathrm{T}$ cells to CD95 (Fas/Apo-1) ligand-mediated cell death after activation in vitro versus in vivo. J Immunol 156: 2357-2360.

Ehrhardt H, Fulda S, Schmid I, Hiscott J, Debatin KM, Jeremias I. 2003. TRAIL induced survival and proliferation in cancer cells resistant towards TRAIL-induced apoptosis mediated by NF-кB. Oncogene 22: 3842-3852.

Freiberg RA, Spencer DM, Choate KA, Duh HJ, Schreiber SL, Crabtree GR, Khavari PA. 1997. Fas signal transduction triggers either proliferation or apoptosis in human fibroblasts. J Invest Dermatol 108: 215-219.

Galle PR, Hofmann WJ, Walczak H, Schaller H, Otto G, Stremmel W, Krammer PH, Runkel L. 1995. Involvement of the CD95 (APO-1/Fas) receptor and ligand in liver damage. J Exp Med 182: 1223-1230.

Ganten TM, Koschny R, Haas TL, Sykora J, Li-Weber M, Herzer K, Walczak H. 2005. Proteasome inhibition sensitizes hepatocellular carcinoma cells, but not human hepatocytes, to TRAIL. Hepatology 42: 588-597.

Ganten TM, Koschny R, Sykora J, Schulze-Bergkamen H, Buchler P, Haas TL, Schader MB, Untergasser A, Stremmel W, Walczak H. 2006. Preclinical differentiation between apparently safe and potentially hepatotoxic applications of TRAIL either alone or in combination with chemotherapeutic drugs. Clin Cancer Res 12: 2640-2646.

Gerlach B, Cordier SM, Schmukle AC, Emmerich CH, Rieser E, Haas TL, Webb AI, Rickard JA, Anderton H, Wong WW, et al. 2011. Linear ubiquitination prevents inflammation and regulates immune signalling. Nature 471: 591-596.

Green DR. 2010. Cancer: A wolf in wolf's clothing. Nature 465: 433 .

* Green DR. 2013. Mitos, MOMP, and death. Cold Spring Harb Perspect Biol doi: 10.1101/cshperspect.a008706.

Gross A, Yin XM, Wang K, Wei MC, Jockel J, Milliman C, Erdjument-Bromage H, Tempst P, Korsmeyer SJ. 1999. Caspase cleaved BID targets mitochondria and is required for cytochrome $c$ release, while BCL-XL prevents this release but not tumor necrosis factor-R1/Fas death. J Biol Chem 274: 1156-1163.

Gunther C, Martini E, Wittkopf N, Amann K, Weigmann B, Neumann H, Waldner MJ, Hedrick SM, Tenzer S, Neurath MF, et al. 2012. Caspase-8 regulates TNF- $\alpha$-induced epithelial necroptosis and terminal ileitis. Nature 477: 335-339.

Hall SS. 1997. A commotion in the blood: Life, death, and the immune system. Holt, New York.

He S, Wang L, Miao L, Wang T, Du F, Zhao L, Wang X. 2009. Receptor interacting protein kinase-3 determines cellular necrotic response to TNF- $\alpha$. Cell 137: 1100-1111.

Hitomi J, Christofferson DE, Ng A, Yao J, Degterev A, Xavier RJ, Yuan J. 2008. Identification of a molecular signaling network that regulates a cellular necrotic cell death pathway. Cell 135: 1311-1323.

Holler N, Zaru R, Micheau O, Thome M, Attinger A, Valitutti S, Bodmer JL, Schneider P, Seed B, Tschopp J. 2000. Fas triggers an alternative, caspase-8-independent cell death pathway using the kinase RIP as effector molecule. Nat Immunol 1: 489-495.

Irmler M, Thome M, Hahne M, Schneider P, Hofmann K, Steiner V, Bodmer JL, Schroter M, Burns K, Mattmann C, et al. 1997. Inhibition of death receptor signals by cellular FLIP. Nature 388: 190-195.

Itoh N, Nagata S. 1993. A novel protein domain required for apoptosis. Mutational analysis of human Fas antigen. $J$ Biol Chem 268: 10932-10937.

Itoh $\mathrm{N}$, Yonehara S, Ishii $\mathrm{A}$, Yonehara M, Mizushima S, Sameshima M, Hase A, Seto Y, Nagata S. 1991. The polypeptide encoded by the cDNA for human cell surface antigen Fas can mediate apoptosis. Cell 66: 233-243.

Jeremias I, Kupatt C, Martin-Villalba A, Habazettl H, Schenkel J, Boekstegers P, Debatin KM. 2000. Involvement of CD95/Apo1/Fas in cell death after myocardial ischemia. Circulation 102: 915-920.

Jost PJ, Grabow S, Gray D, McKenzie MD, Nachbur U, Huang DC, Bouillet P, Thomas HE, Borner C, Silke J, et al. 2009. XIAP discriminates between type I and type II FAS-induced apoptosis. Nature 460: 1035-1039.

Ju ST, Panka DJ, Cui H, Ettinger R, el-Khatib M, Sherr DH, Stanger BZ, Marshak-Rothstein A. 1995. Fas(CD95)/ FasL interactions required for programmed cell death after T-cell activation. Nature 373: 444-448.

Kaiser WJ, Upton JW, Long AB, Livingston-Rosanoff D, Daley-Bauer LP, Hakem R, Caspary T, Mocarski ES. 2011. RIP3 mediates the embryonic lethality of caspase-8-deficient mice. Nature 471: 368-372.

Kavuri SM, Geserick P, Berg D, Dimitrova DP, Feoktistova M, Siegmund D, Gollnick H, Neumann M, Wajant H, Leverkus M. 2011. Cellular FLICE-inhibitory protein (cFLIP) isoforms block CD95- and TRAIL death receptor-induced gene induction irrespective of processing of caspase- 8 or cFLIP in the death-inducing signaling complex. J Biol Chem 286: 16631-16646.

Kennedy NJ, Kataoka T, Tschopp J, Budd RC. 1999. Caspase activation is required for T cell proliferation. J Exp Med 190: $1891-1896$.

Kischkel FC, Hellbardt S, Behrmann I, Germer M, Pawlita M, Krammer PH, Peter ME. 1995. Cytotoxicity-dependent APO-1 (Fas/CD95)-associated proteins form a death-inducing signaling complex (DISC) with the receptor. EMBO J 14: 5579-5588.

Kischkel FC, Lawrence DA, Chuntharapai A, Schow P, Kim KJ, Ashkenazi A. 2000. Apo2L/TRAIL-dependent recruitment of endogenous FADD and caspase- 8 to death receptors 4 and 5. Immunity 12: 611-620.

Kischkel FC, Lawrence DA, Tinel A, LeBlanc H, Virmani A, Schow P, Gazdar A, Blenis J, Arnott D, Ashkenazi A. 2001. Death receptor recruitment of endogenous caspase-10 and apoptosis initiation in the absence of caspase-8. J Biol Chem 276: 46639-46646.

Kitson J, Raven T, Jiang YP, Goeddel DV, Giles KM, Pun KT, Grinham CJ, Brown R, Farrow SN. 1996. A death-domain-containing receptor that mediates apoptosis. $\mathrm{Na}$ ture 384: 372-375.

Kleber S, Sancho-Martinez I, Wiestler B, Beisel A, Gieffers C, Hill O, Thiemann M, Mueller W, Sykora J, Kuhn A, et al. 2008. Yes and PI3K bind CD 95 to signal invasion of glioblastoma. Cancer Cell 13: 235-248. 
H. Walczak

Komander D, Clague MJ, Urbe S. 2009a. Breaking the chains: Structure and function of the deubiquitinases. Nat Rev Mol Cell Biol 10: 550-563.

Komander D, Reyes-Turcu F, Licchesi JD, Odenwaelder P, Wilkinson KD, Barford D. 2009b. Molecular discrimination of structurally equivalent Lys 63-linked and linear polyubiquitin chains. EMBO Rep 10: 466-473.

Kondo T, Suda T, Fukuyama H, Adachi M, Nagata S. 1997. Essential roles of the Fas ligand in the development of hepatitis. Nat Med 3: 409-413.

Koschny R, Ganten TM, Sykora J, Haas TL, Sprick MR, Kolb A, Stremmel W, Walczak H. 2007. TRAIL/bortezomib cotreatment is potentially hepatotoxic but induces cancer-specific apoptosis within a therapeutic window. Hepatology 45: 649-658.

Kovalenko A, Kim JC, Kang TB, Rajput A, Bogdanov K, Dittrich-Breiholz O, Kracht M, Brenner O, Wallach D. 2009. Caspase-8 deficiency in epidermal keratinocytes triggers an inflammatory skin disease. J Exp Med 206: 2161-2177.

Lawrence D, Shahrokh Z, Marsters S, Achilles K, Shih D, Mounho B, Hillan K, Totpal K, DeForge L, Schow P, et al. 2001. Differential hepatocyte toxicity of recombinant Apo2L/TRAIL versions. Nat Med 7: 383-385.

Lee P, Sata M, Lefer DJ, Factor SM, Walsh K, Kitsis RN. 2003. Fas pathway is a critical mediator of cardiac myocyte death and MI during ischemia-reperfusion in vivo. Am J Physiol Heart Circ Physiol 284: H456-H463.

Lemke J, Noack A, Adam D, Tchikov V, Bertsch U, Roder C, Schutze S, Wajant H, Kalthoff H, Trauzold A. 2010. TRAIL signaling is mediated by DR4 in pancreatic tumor cells despite the expression of functional DR5. J Mol Med (Berl) 88: 729-740.

Lo YC, Lin SC, Rospigliosi CC, Conze DB, Wu CJ, Ashwell JD, Eliezer D, Wu H. 2009. Structural basis for recognition of diubiquitins by NEMO. Mol Cell 33: 602-615.

Loetscher H, Pan YC, Lahm HW, Gentz R, Brockhaus M, Tabuchi H, Lesslauer W. 1990. Molecular cloning and expression of the human $55 \mathrm{kd}$ tumor necrosis factor receptor. Cell 61: 351-359.

Lowin B, Beermann F, Schmidt A, Tschopp J. 1994a. A null mutation in the perforin gene impairs cytolytic T lymphocyte- and natural killer cell-mediated cytotoxicity. Proc Natl Acad Sci 91: 11571-11575.

Lowin B, Hahne M, Mattmann C, Tschopp J. 1994b. Cytolytic T-cell cytotoxicity is mediated through perforin and Fas lytic pathways. Nature 370: 650-652.

Marsters SA, Pitti RM, Donahue CJ, Ruppert S, Bauer KD, Ashkenazi A. 1996. Activation of apoptosis by Apo-2 ligand is independent of FADD but blocked by CrmA. Curr Biol 6: 750-752.

Martin-Villalba A, Herr I, Jeremias I, Hahne M, Brandt R, Vogel J, Schenkel J, Herdegen T, Debatin KM. 1999. CD95 ligand (Fas-L/APO-1L) and tumor necrosis factor-related apoptosis-inducing ligand mediate ischemia-induced apoptosis in neurons. J Neurosci 19: 3809-3817.

Micheau O, Tschopp J. 2003. Induction of TNF receptor Imediated apoptosis via two sequential signaling complexes. Cell 114: 181-190.
Migone TS, Zhang J, Luo X, Zhuang L, Chen C, Hu B, Hong JS, Perry JW, Chen SF, Zhou JX, et al. 2002. TL1A is a TNF-like ligand for DR3 and TR6/DcR3 and functions as a $\mathrm{T}$ cell costimulator. Immunity 16: 479-492.

Miwa K, Hashimoto H, Yatomi T, Nakamura N, Nagata S, Suda T. 1999. Therapeutic effect of an anti-Fas ligand $\mathrm{mAb}$ on lethal graft-versus-host disease. Int Immunol 11: $925-931$.

Muzio M, Chinnaiyan AM, Kischkel FC, O'Rourke K, Shevchenko A, Ni J, Scaffidi C, Bretz JD, Zhang M, Gentz R, et al. 1996. FLICE, a novel FADD-homologous ICE/CED-3-like protease, is recruited to the CD95 (Fas/ APO-1) death-inducing signaling complex. Cell 85: 817-827.

Nauts HC, Swift WE, Coley BL. 1946. The treatment of malignant tumors by bacterial toxins as developed by the late William B. Coley, M.D., reviewed in the light of modern research. Cancer Res 6: 205-216.

Nauts HC, Fowler GA, Bogatko FH. 1953. A review of the influence of bacterial infection and of bacterial products (Coley's toxins) on malignant tumors in man; a critical analysis of 30 inoperable cases treated by Coley's mixed toxins, in which diagnosis was confirmed by microscopic examination selected for special study. Acta Med Scand Suppl 276: 1-103.

Newsom-Davis T, Prieske S, Walczak H. 2009. Is TRAIL the holy grail of cancer therapy? Apoptosis 14: 607-623.

Nikolaev A, McLaughlin T, O’Leary DD, Tessier-Lavigne M. 2009. APP binds DR6 to trigger axon pruning and neuron death via distinct caspases. Nature 457: 981-989.

Oberst A, Dillon CP, Weinlich R, McCormick LL, Fitzgerald P, Pop C, Hakem R, Salvesen GS, Green DR. 2011. Catalytic activity of the caspase-8-FLIP(L) complex inhibits RIPK3-dependent necrosis. Nature 471: $363-$ 367.

Oehm A, Behrmann I, Falk W, Pawlita M, Maier G, Klas C, Li-Weber M, Richards S, Dhein J, Trauth BC, et al. 1992. Purification and molecular cloning of the APO-1 cell surface antigen, a member of the tumor necrosis factor/nerve growth factor receptor superfamily. Sequence identity with the Fas antigen. J Biol Chem 267: 1070910715.

Ogasawara J, Watanabe-Fukunaga R, Adachi M, Matsuzawa A, Kasugai T, Kitamura Y, Itoh N, Suda T, Nagata S. 1993. Lethal effect of the anti-Fas antibody in mice. Nature 364: 806-809.

Owen-Schaub LB, Meterissian S, Ford RJ. 1993. Fas/APO-1 expression and function on malignant cells of hematologic and nonhematologic origin. J Immunother Emphasis Tumor Immunol 14: 234-241.

Oyaizu T, Shikata N, Senzaki H, Matsuzawa A, Tsubura A. 1997. Studies on the mechanism of dimethylnitrosamine-induced acute liver injury in mice. Exp Toxicol Pathol 49: 375-380.

Pan G, Ni J, Wei YF, Yu G, Gentz R, Dixit VM. 1997a. An antagonist decoy receptor and a death domain-containing receptor for TRAIL. Science 277: 815-818.

Pan G, O’Rourke K, Chinnaiyan AM, Gentz R, Ebner R, Ni J, Dixit VM. 1997b. The receptor for the cytotoxic ligand TRAIL. Science 276: 111-113.

Pan G, Bauer JH, Haridas V, Wang S, Liu D, Yu G, Vincenz C, Aggarwal BB, Ni J, Dixit VM. 1998. Identification and 
functional characterization of DR6, a novel death domain-containing TNF receptor. FEBS Lett 431: 351-356.

* Parrish AB, Freel CD, Kornbluth S. 2013. Cellular mechanisms controlling caspase activation and function. Cold Spring Harb Perspect Biol doi: 10.1101/cshperspect. a008672.

Peter ME, Krammer PH. 1998. Mechanisms of CD95 (APO1/Fas)-mediated apoptosis. Curr Opin Immunol 10: 545-551.

Peter ME, Budd RC, Desbarats J, Hedrick SM, Hueber AO, Newell MK, Owen LB, Pope RM, Tschopp J, Wajant H, et al. 2007. The CD95 receptor: Apoptosis revisited. Cell 129: $447-450$.

Pitti RM, Marsters SA, Ruppert S, Donahue CJ, Moore A, Ashkenazi A. 1996. Induction of apoptosis by Apo-2 ligand, a new member of the tumor necrosis factor cytokine family. J Biol Chem 271: 12687-12690.

Pop C, Salvesen GS. 2009. Human caspases: Activation, specificity, and regulation. J Biol Chem 284: 21777-21781.

Rahighi S, Ikeda F, Kawasaki M, Akutsu M, Suzuki N, Kato R, Kensche T, Uejima T, Bloor S, Komander D, et al. 2009. Specific recognition of linear ubiquitin chains by NEMO is important for NF-кB activation. Cell 136: 1098-1109.

Reap EA, Sobel ES, Cohen PL, Eisenberg RA. 1993. Conventional $\mathrm{B}$ cells, not B-1 cells, are responsible for producing autoantibodies in lpr mice. J Exp Med 177: 69-78.

Rieser E, Schmukle AC, Walczak H. 2012. Linear ubiquitination: A newly discovered regulator of cell signalling. Trends Biochem Sci 24: 229-231.

Roder C, Trauzold A, Kalthoff H. 2011. Impact of death receptor signaling on the malignancy of pancreatic ductal adenocarcinoma. Eur J Cell Biol 90: 450-455.

Roths JB, Murphy ED, Eicher EM. 1984. A new mutation, gld, that produces lymphoproliferation and autoimmunity in $\mathrm{C} 3 \mathrm{H} / \mathrm{HeJ}$ mice. J Exp Med 159: 1-20.

Salvesen GS, Riedl SJ. 2008. Caspase mechanisms. Adv Exp Med Biol 615: 13-23.

Sancho-Martinez I, Martin-Villalba A. 2009. Tyrosine phosphorylation and CD95: A FAScinating switch. Cell Cycle 8: $838-842$.

Schall TJ, Lewis M, Koller KJ, Lee A, Rice GC, Wong GH, Gatanaga T, Granger GA, Lentz R, Raab H, et al. 1990. Molecular cloning and expression of a receptor for human tumor necrosis factor. Cell 61: 361-370.

Schleich K, Warnken U, Fricker N, Ozturk S, Richter P, Kammerer K, Schnolzer M, Krammer PH, Lavrik IN. 2012. Stoichiometry of the CD95 death-inducing signaling complex: Experimental and modeling evidence for a death effector domain chain model. Mol Cell 47: 306-319.

Screaton GR, Mongkolsapaya J, Xu XN, Cowper AE, McMichael AJ, Bell JI. 1997a. TRICK2, a new alternatively spliced receptor that transduces the cytotoxic signal from TRAIL. Curr Biol 7: 693-696.

Screaton GR, Xu XN, Olsen AL, Cowper AE, Tan R, McMichael AJ, Bell JI. 1997b. LARD: A new lymphoidspecific death domain containing receptor regulated by alternative pre-mRNA splicing. Proc Natl Acad Sci 94: 4615-4619.
Shear MJ, Perrault A. 1944. A chemical treatment of tumors. IX. Reactions of mice with primary subcutaneous tumors to injection of a hemorrhage-producing bacterial polysaccharide. J Natl Cancer Inst 44: 461-476.

Sheridan JP, Marsters SA, Pitti RM, Gurney A, Skubatch M, Baldwin D, Ramakrishnan L, Gray CL, Baker K, Wood WI, et al. 1997. Control of TRAIL-induced apoptosis by a family of signaling and decoy receptors. Science 277: 818-821.

Simonet WS, Lacey DL, Dunstan CR, Kelley M, Chang MS, Luthy R, Nguyen HQ, Wooden S, Bennett L, Boone T, et al. 1997. Osteoprotegerin: A novel secreted protein involved in the regulation of bone density. Cell 89: 309-319.

Smith CA, Davis T, Anderson D, Solam L, Beckmann MP, Jerzy R, Dower SK, Cosman D, Goodwin RG. 1990. A receptor for tumor necrosis factor defines an unusual family of cellular and viral proteins. Science 248: 10191023.

Sprick MR, Weigand MA, Rieser E, Rauch CT, Juo P, Blenis J, Krammer PH, Walczak H. 2000. FADD/MORT1 and caspase- 8 are recruited to TRAIL receptors 1 and 2 and are essential for apoptosis mediated by TRAIL receptor 2 . Immunity 12: 599-609.

Sprick MR, Rieser E, Stahl H, Grosse-Wilde A, Weigand MA, Walczak H. 2002. Caspase-10 is recruited to and activated at the native TRAIL and CD95 death-inducing signalling complexes in a FADD-dependent manner but can not functionally substitute caspase-8. EMBO J 21: 45204530.

Strand S, Hofmann WJ, Grambihler A, Hug H, Volkmann M, Otto G, Wesch H, Mariani SM, Hack V, Stremmel W, et al. 1998. Hepatic failure and liver cell damage in acute Wilson's disease involve CD95 (APO1/Fas) mediated apoptosis. Nat Med 4: 588-593.

Strand S, Strand D, Seufert R, Mann A, Lotz J, Blessing M, Lahn M, Wunsch A, Broering DC, Hahn U, et al. 2004 Placenta-derived CD95 ligand causes liver damage in hemolysis, elevated liver enzymes, and low platelet count syndrome. Gastroenterology 126: 849-858.

Suda T, Nagata S. 1994. Purification and characterization of the Fas-ligand that induces apoptosis. J Exp Med 179: 873-879.

Suda T, Takahashi T, Golstein P, Nagata S. 1993. Molecular cloning and expression of the Fas ligand, a novel member of the tumor necrosis factor family. Cell 75: 1169-1178.

Takahashi T, Tanaka M, Brannan CI, Jenkins NA, Copeland NG, Suda T, Nagata S. 1994. Generalized lymphoproliferative disease in mice, caused by a point mutation in the Fas ligand. Cell 76: 969-976.

Tartaglia LA, Ayres TM, Wong GH, Goeddel DV. 1993. A novel domain within the $55 \mathrm{kd}$ TNF receptor signals cell death. Cell 74: 845-853.

Taylor PC, Feldmann M. 2009. Anti-TNF biologic agents: Still the therapy of choice for rheumatoid arthritis. Nat Rev Rheumatol 5: 578-582.

Thome M, Schneider P, Hofmann K, Fickenscher H, Meinl E, Neipel F, Mattmann C, Burns K, Bodmer JL, Schroter M, et al. 1997. Viral FLICE-inhibitory proteins (FLIPs) prevent apoptosis induced by death receptors. Nature 386: 517-521. 
H. Walczak

Thornberry NA, Bull HG, Calaycay JR, Chapman KT, Howard AD, Kostura MJ, Miller DK, Molineaux SM, Weidner JR, Aunins J, et al. 1992. A novel heterodimeric cysteine protease is required for interleukin- $1 \beta$ processing in monocytes. Nature 356: 768-774.

Tracey KJ, Lowry SF, Cerami A. 1988. Cachetin/TNF- $\alpha$ in septic shock and septic adult respiratory distress syndrome. Am Rev Respir Dis 138: 1377-1379.

Trauth BC, Klas C, Peters AM, Matzku S, Moller P, Falk W, Debatin KM, Krammer PH. 1989. Monoclonal antibodymediated tumor regression by induction of apoptosis. Science 245: 301-305.

Vandenabeele P, Galluzzi L, Vanden Berghe T, Kroemer G. 2010. Molecular mechanisms of necroptosis: An ordered cellular explosion. Nat Rev Mol Cell Biol 11: 700-714.

van Raam BJ, Salvesen GS. 2012. Proliferative versus apoptotic functions of caspase- 8 Hetero or homo: The caspase-8 dimer controls cell fate. Biochim Biophys Acta 1824: $113-122$.

Varfolomeev E, Maecker H, Sharp D, Lawrence D, Renz M Vucic D, Ashkenazi A. 2005. Molecular determinants of kinase pathway activation by Apo2 ligand/tumor necrosis factor-related apoptosis-inducing ligand. J Biol Chem 280: 40599-40608.

Via CS, Nguyen P, Shustov A, Drappa J, Elkon KB. 1996a. A major role for the Fas pathway in acute graft-versus-host disease. J Immunol 157: 5387-5393.

Via CS, Rus V, Nguyen P, Linsley P, Gause WC. 1996b. Differential effect of CTLA4Ig on murine graft-versus-host disease (GVHD) development: CTLA4Ig prevents both acute and chronic GVHD development but reverses only chronic GVHD. J Immunol 157: 4258-4267.

Vince JE, Wong WW, Gentle I, Lawlor KE, Allam R, O'Reilly L, Mason K, Gross O, Ma S, Guarda G, et al. 2012. Inhibitor of apoptosis proteins limit RIP3 kinasedependent interleukin-1 activation. Immunity 36: 215 227.

Vogt M, Bauer MK, Ferrari D, Schulze-Osthoff K. 1998. Oxidative stress and hypoxia/reoxygenation trigger CD95 (APO-1/Fas) ligand expression in microglial cells. FEBS Lett 429: 67-72.

Wajant H, Pfizenmaier K, Scheurich P. 2003. Tumor necrosis factor signaling. Cell Death Differ 10: 45-65.

Walczak H. 2011. TNF and ubiquitin at the crossroads of gene activation, cell death, inflammation, and cancer. Immunol Rev 244: 9-28.

Walczak H, Krammer PH. 2000. The CD95 (APO-1/Fas) and the TRAIL (APO-2L) apoptosis systems. Exp Cell Res 256: $58-66$.

Walczak H, Degli-Esposti MA, Johnson RS, Smolak PJ, Waugh JY, Boiani N, Timour MS, Gerhart MJ, Schooley KA, Smith CA, et al. 1997. TRAIL-R2: A novel apoptosis-mediating receptor for TRAIL. EMBO J 16: 5386-5397.

Walczak H, Miller RE, Ariail K, Gliniak B, Griffith TS, Kubin M, Chin W, Jones J, Woodward A, Le T, et al. 1999. Tumoricidal activity of tumor necrosis factor-related apoptosis-inducing ligand in vivo. Nat Med 5: 157163.
Wallach D, Kovalenko A, Kang TB. 2012. ""Necrosome"induced inflammation: Must cells die for it? Trends Immunol 32: 505-509.

Watanabe-Fukunaga R, Brannan CI, Copeland NG, Jenkins NA, Nagata S. 1992. Lymphoproliferation disorder in mice explained by defects in Fas antigen that mediates apoptosis. Nature 356: 314-317.

Welz PS, Wullaert A, Vlantis K, Kondylis V, FernandezMajada V, Ermolaeva M, Kirsch P, Sterner-Kock A, van Loo G, Pasparakis M. 2011. FADD prevents RIP3-mediated epithelial cell necrosis and chronic intestinal inflammation. Nature 477: 330-334.

Wiley SR, Schooley K, Smolak PJ, Din WS, Huang CP, Nicholl JK, Sutherland GR, Smith TD, Rauch C, Smith CA, et al. 1995. Identification and characterization of a new member of the TNF family that induces apoptosis. Immunity 3: 673-682.

Williams RO, Feldmann M, Maini RN. 1992. Anti-tumor necrosis factor ameliorates joint disease in murine collagen-induced arthritis. Proc Natl Acad Sci 89: 9784-9788.

Wilson NS, Dixit V, Ashkenazi A. 2009. Death receptor signal transducers: Nodes of coordination in immune signaling networks. Nat Immunol 10: 348-355.

Wilson NS, Yang B, Yang A, Loeser S, Marsters S, Lawrence D, Li Y, Pitti R, Totpal K, Yee S, et al. 2011. An Fc $\gamma$ receptor-dependent mechanism drives antibodymediated target-receptor signaling in cancer cells. Cancer Cell 19: $101-113$.

Wu GS, Burns TF, McDonald ER 3rd, Jiang W, Meng R, Krantz ID, Kao G, Gan DD, Zhou JY, Muschel R, et al. 1997. KILLER/DR5 is a DNA damage-inducible p53regulated death receptor gene. Nat Genet 17: 141-143.

Yeh WC, Itie A, Elia AJ, Ng M, Shu HB, Wakeham A, Mirtsos C, Suzuki N, Bonnard M, Goeddel DV, et al. 2000. Requirement for Casper (c-FLIP) in regulation of death receptor-induced apoptosis and embryonic development. Immunity 12: 633-642.

Yin XM, Wang K, Gross A, Zhao Y, Zinkel S, Klocke B, Roth KA, Korsmeyer SJ. 1999. Bid-deficient mice are resistant to Fas-induced hepatocellular apoptosis. Nature 400: 886-891.

Yonehara S, Ishii A, Yonehara M. 1989. A cell-killing monoclonal antibody (anti-Fas) to a cell surface antigen codownregulated with the receptor of tumor necrosis factor. J Exp Med 169: 1747-1756.

Yuan JY, Horvitz HR. 1990. The Caenorhabditis elegans genes ced-3 and ced-4 act cell autonomously to cause programmed cell death. Dev Biol 138: 33-41.

Yuan J, Shaham S, Ledoux S, Ellis HM, Horvitz HR. 1993. The C. elegans cell death gene ced-3 encodes a protein similar to mammalian interleukin-1 $\beta$-converting enzyme. Cell 75: 641-652.

Zhang DW, Shao J, Lin J, Zhang N, Lu BJ, Lin SC, Dong MQ, Han J. 2009. RIP3, an energy metabolism regulator that switches TNF-induced cell death from apoptosis to necrosis. Science 325: 332-336.

Zhang H, Zhou X, McQuade T, Li J, Chan FK, Zhang J. 2011. Functional complementation between FADD and RIP1 in embryos and lymphocytes. Nature 471: 373-376. 


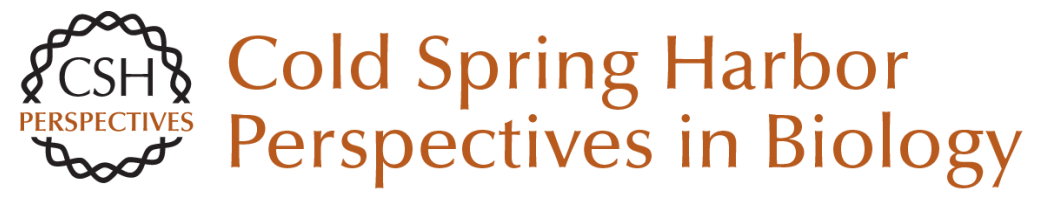

\section{Death Receptor-Ligand Systems in Cancer, Cell Death, and Inflammation}

Henning Walczak

Cold Spring Harb Perspect Biol 2013; doi: 10.1101/cshperspect.a008698

Subject Collection Cell Survival and Cell Death

Programmed Cell Death in the Evolutionary Race against Bacterial Virulence Factors

Carolyn A. Lacey and Edward A. Miao

The Evolutionary Origins of Programmed Cell

Death Signaling

Kay Hofmann

Regulation of Cell Death and Immunity by XIAP Philipp J. Jost and Domagoj Vucic

Dysregulation of Cell Death in Human Chronic Inflammation

Yue Li, Christoph Klein and Daniel Kotlarz

Cell Death in Plant Immunity

Eugenia Pitsili, Ujjal J. Phukan and Nuria S. Coll

Recent Insights on Inflammasomes, Gasdermin

Pores, and Pyroptosis

Nathalia M. de Vasconcelos and Mohamed Lamkanfi

Phagocyte Responses to Cell Death in Flies Andrew J. Davidson and Will Wood

Mechanism and Regulation of Gasdermin-Mediated Cell Death

Shiyu Xia, Louis Robert Hollingsworth IV and Hao
Cell Death and Neurodegeneration

Benjamin J. Andreone, Martin Larhammar and Joseph W. Lewcock

Death Receptors and Their Ligands in

Inflammatory Disease and Cancer Alessandro Annibaldi and Henning Walczak

The Killer Pseudokinase Mixed Lineage Kinase Domain-Like Protein (MLKL) James M. Murphy

Neutrophil Extracellular Traps in Host Defense Sabrina Sofia Burgener and Kate Schroder

Cell-Cycle Cross Talk with Caspases and Their

Substrates

Patrick Connolly, Irmina Garcia-Carpio and Andreas Villunger

Cracking the Cell Death Code

Carla V. Rothlin and Sourav Ghosh

BAX, BAK, and BOK: A Coming of Age for the BCL-2 Family Effector Proteins

Tudor Moldoveanu and Peter E. Czabotar

Multitasking Kinase RIPK1 Regulates Cell Death and Inflammation

Kim Newton

For additional articles in this collection, see http://cshperspectives.cshlp.org/cgi/collection/

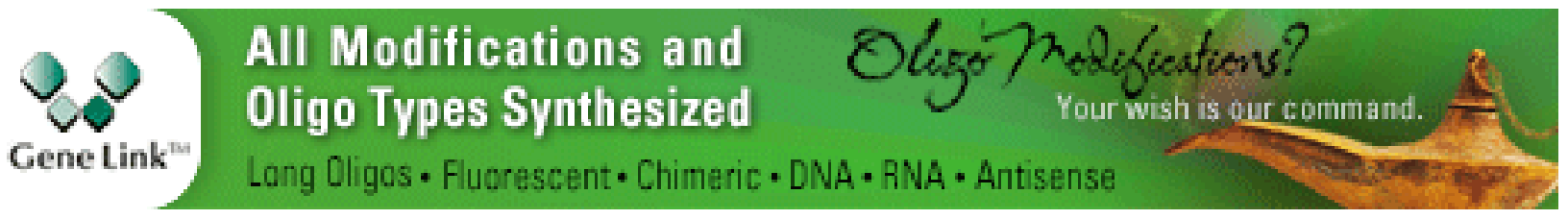

Copyright @ 2013 Cold Spring Harbor Laboratory Press; all rights reserved 
For additional articles in this collection, see http://cshperspectives.cshlp.org/cgi/collection/

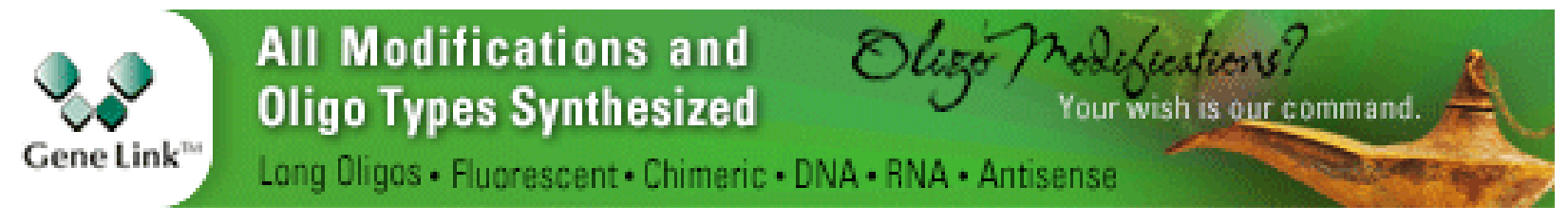

Copyright @ 2013 Cold Spring Harbor Laboratory Press; all rights reserved 